\title{
Soft-sediment deformation structures interpreted as seismites in lacustrine sediments of the Prebetic Zone, SE Spain, and their potential use as indicators of earthquake magnitudes during the Late Miocene
}

\author{
M.A. Rodríguez-Pascua ${ }^{\mathrm{a}, *}$, J.P. Calvo ${ }^{\mathrm{b}}$, G. De Vicente ${ }^{\mathrm{a}}$, D. Gómez-Gras ${ }^{\mathrm{c}}$ \\ ${ }^{a}$ Departamento de Geodinámica, Facultad CC. Geológicas, Universidad Complutense, 28040 Madrid, Spain \\ ${ }^{\mathrm{b}}$ Departamento de Petrología y Geoquímica, Facultad CC. Geológicas, Universidad Complutense, 28040 Madrid, Spain \\ ${ }^{\mathrm{c}}$ Departamento de Geología, Facultad de Ciencias, Universidad Autónoma de Barcelona, 08193 Bellaterra, Barcelona, Spain
}

\begin{abstract}
Lacustrine formations of Late Miocene age in the Prebetic area, SE Spain, show several types of deformational structures that are interpreted as seismites. They are present in both marginal and deep lacustrine facies. Seismites formed in marginal lake environments comprise sand dikes, pillows and intruded and fractured gravels. In deep lacustrine facies, the seismites are represented by pseudonodules, mushroom-like silts protruding into laminites, mixed layers, disturbed varved lamination and loop bedding. The measured orientations of these structures are consistent with the orientations of the main faults limiting the basins, showing that their origin is clearly related to the tectonic stress field that prevailed in the region during the Late Miocene. The magnitudes of the earthquakes that deformed the sediments have been estimated after published data from both ancient and recent lake deposits accumulated in tectonic active regions elsewhere. A rank of earthquake magnitudes with two end-members, i.e. the lowest magnitudes recorded by loop bedding in laminites and the highest magnitudes represented by intruded and fractured gravels, is proposed.
\end{abstract}

Keywords: seismites; earthquake magnitudes; Lacustrine deposits; Late Miocene; Spain

\section{Introduction}

Recognition of seismic events in the stratigraphic record has become a highly suggestive task for earth scientists. Besides the fascinating stimulation that catastrophic events mean for the human psiche, identifying the occurrence and effects of earthquakes in

\footnotetext{
* Corresponding author. Fax: +34-91-544-2535.

E-mail addresses: mpascua@eucemos.sim.ucm.es

(M.A. Rodríguez-Pascua), jpcalvo@eucmax.sim.ucm.es

(J.P. Calvo), d.gomez@geologia.uab.es (D. Gomez-Gras).
}

the past, a relatively new discipline known as Palaeoseismology (Serva and Slemmons, 1995; Yeats et al., 1997), is a matter of major interest for both basic and applied purposes, e.g. paleotectonic reconstructions, sedimentation-tectonics relationships in basins, sedimentary facies analysis, and evaluation of earthquake hazard for the emplacement of nuclear power plants and, in general, land management.

Seismites are deformational structures attributable to seismic shocks. Seilacher (1969) introduced this term for a graded sequence of structures (fault-graded beds), ranging from undisturbed sediment to liquified, 

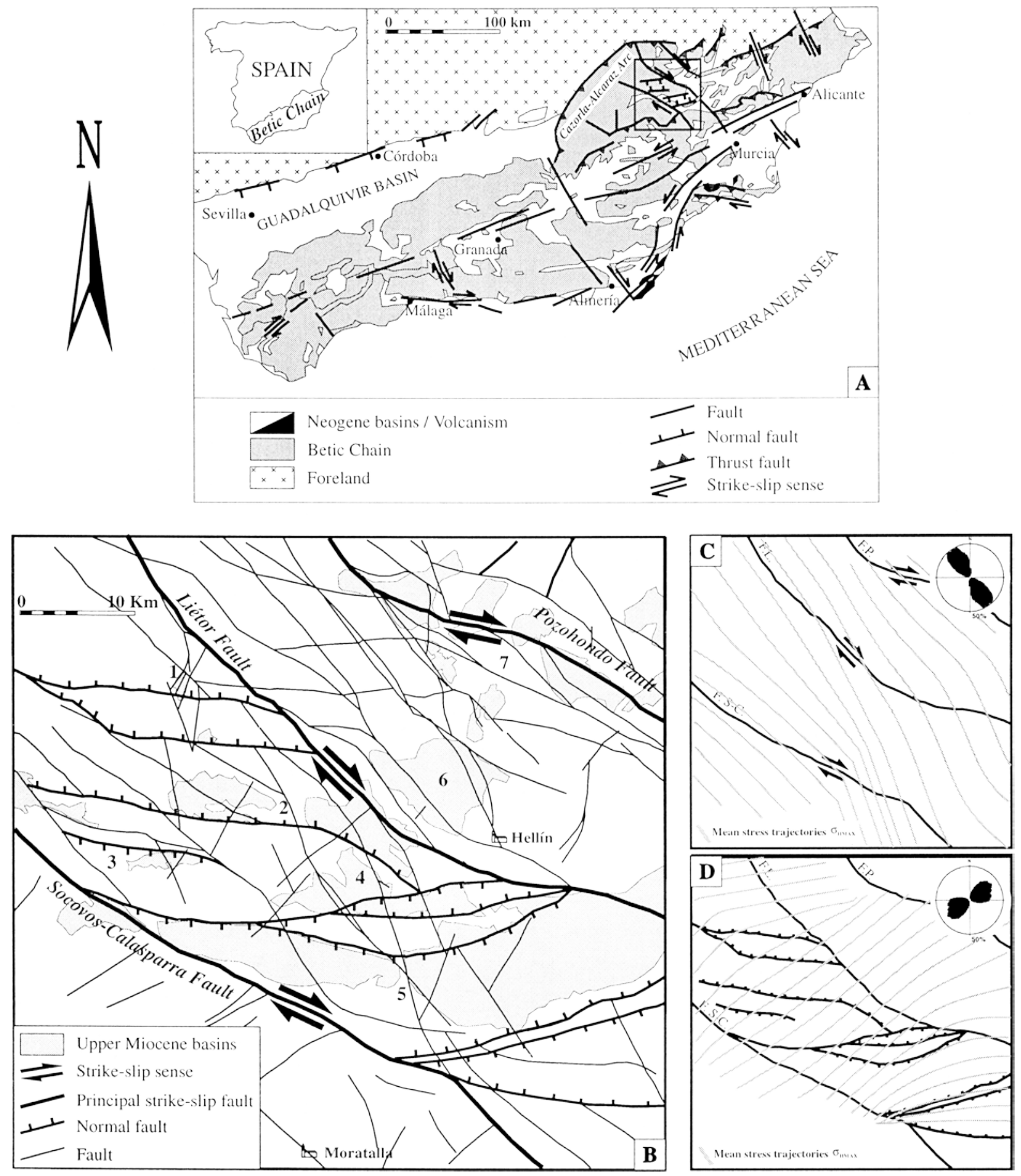

Fig. 1. Geological context and characteristics of the tectonic stress field of the study area. (A) Sketch map with location of the External Zones of the Betic Chain in which the Prebetic Zone is included, boxed area encloses the region shown in B. (B) Tectonic framework of the study area, and location of the lake basins developed throughout the Late Miocene. 1, Híjar; 2, Elche de la Sierra; 3, Gallego; 4, Cenajo; 5, Las Minas; 6, Hellín; 7, Pozohondo. (C) and (D) Orientations of the major axes of the palaeostress ellipse in the horizontal plane ( $\sigma_{\text {HMAX }}$ (from Late Miocene to Recent) calculated by brittle deformation tectonic analysis. 
homogeneized sediment, developed in the Monterey Shales (Miocene) of California. Afterwards, a great deal of specialized literature on this topic has come out regarding both description and interpretation of seismites and deposits, which could be caused by seismic effects (for a review, see Sims, 1975; Cita and Ricci Lucchi, 1984; Allen, 1986; Einsele et al., 1991; Serva and Slemmons, 1995; Einsele et al., 1996; Plaziat and Ahamamou, 1998 among others). Despite the profuse documentation, no unequivocal criteria are still available for identifying seismic events in the stratigraphic record in view of the many causes that can result in the deformation of sediments (Ricci Lucchi, 1995). Nonetheless, advances in palaeoseismology through the study of recent fault trenches (McCalpin, 1996) are contributing to improve knowledge of the deformational structures induced by earthquakes.

Some depositional areas, in particular lakes and internal basins, are regarded as most suitable sites for the analysis of seismically induced structures (Ricci Lucchi, 1995). Lake systems show commonly several depositional subenvironments in which a variety of heterolithic facies are sedimented. When lakes are relatively deep, deposition in marginal and central parts is contrasted. The deeper parts of the lakes, frequently behaving as stratified water bodies, receive sediments in which rhythmically laminated sequences are preserved (Anderson and Dean, 1988; Glenn and Kelts, 1991). Anoxic waters near the bottom avoid sediment disturbance by burrowing and the influence of normal and/or storm waves is reduced or none.

In tectonically active areas, the effect of seismic shocks related to fault movements can be imprinted as deformational structures in the lacustrine sediments if the seismic events exceed a certain magnitude and the lithology and compactional state of the sediments allow liquefaction, i.e. loss of shear strength of granule materials saturated with water, or fluidization (Owen, 1996). The pioneering work by Sims (1973, 1975) on the stratigraphic record of seismic shaking was developed in recent lacustrine deposits of California and Washington and provided a sound conceptual basis for paleoseismic studies in this type of sediments.

The present paper describes several occurrences of deformational structures, here interpreted as seismites, in Upper Miocene lacustrine formations accumulated in triaxial extensional basins that developed during a major period of crustal thinning (Van der Beek and Cloething, 1992) in the Prebetic area, SE Spain. The possible seismites are recognized in several facies associations deposited in both marginal and central lake environments. The magnitudes of the earthquakes that may have caused the formation of the seismites are estimated according to data published by several authors. A close relationship between the orientation of the structures and the active tectonic stress field of the region throughout the Upper Miocene to Recent is established. Earthquake recurrence intervals determined from the analysis of seismites in varved sediments will not be treated in this paper. Some information on this subject can be found in Rodríguez-Pascua et al. (1996).

\section{Geological context}

During the Late Miocene, several continental extensional basins (Las Minas, Cenajo, Elche de la Sierra, Gallego, Hijar, Hellín) were formed in the external side of the Betic Chain, the so-called Prebetic Zone, in SE Spain (Sanz de Galdeano and Vera, 1992) (Fig. 1A). The basins display varied extents, ranging from a few $\mathrm{km}^{2}$ (Híjar Basin) to $250 \mathrm{~km}^{2}$ (Las Minas Basin) (Fig. 1B). The basins are typically elongate and formed as rapidly subsiding troughs during the Late Vallesian to Late Turolian (Tortonian-Messinian of the marine chronostratigraphic scale) (Calvo and Elizaga, 1994; Elizaga, 1994). Throughout this time interval, the basins were filled by terrestrial, mainly lacustrine sedimentary deposits reaching up to $500 \mathrm{~m}$ in thickness.

The lake basins are located in a palaeotectonic dextral transfer zone related to the emplacement of a major tectonic thrust, the Cazorla-Alcaraz Arc, characterized by a system of NW verging fault propagation folds related to imbricated thrusts (Fig. 1A). This major tectonic structure developed in the transition from Middle to Upper Miocene. The study area is crossed by three main faults with NW-SE directions: Pozohondo, Liétor and Socovos-Calasparra faults (Martín Velázquez et al., 1998). The two latter faults delimit an area, where the most important lake basins developed during the Late Miocene (Fig. 1B). The basins are bounded by E-W normal faults. Most of 


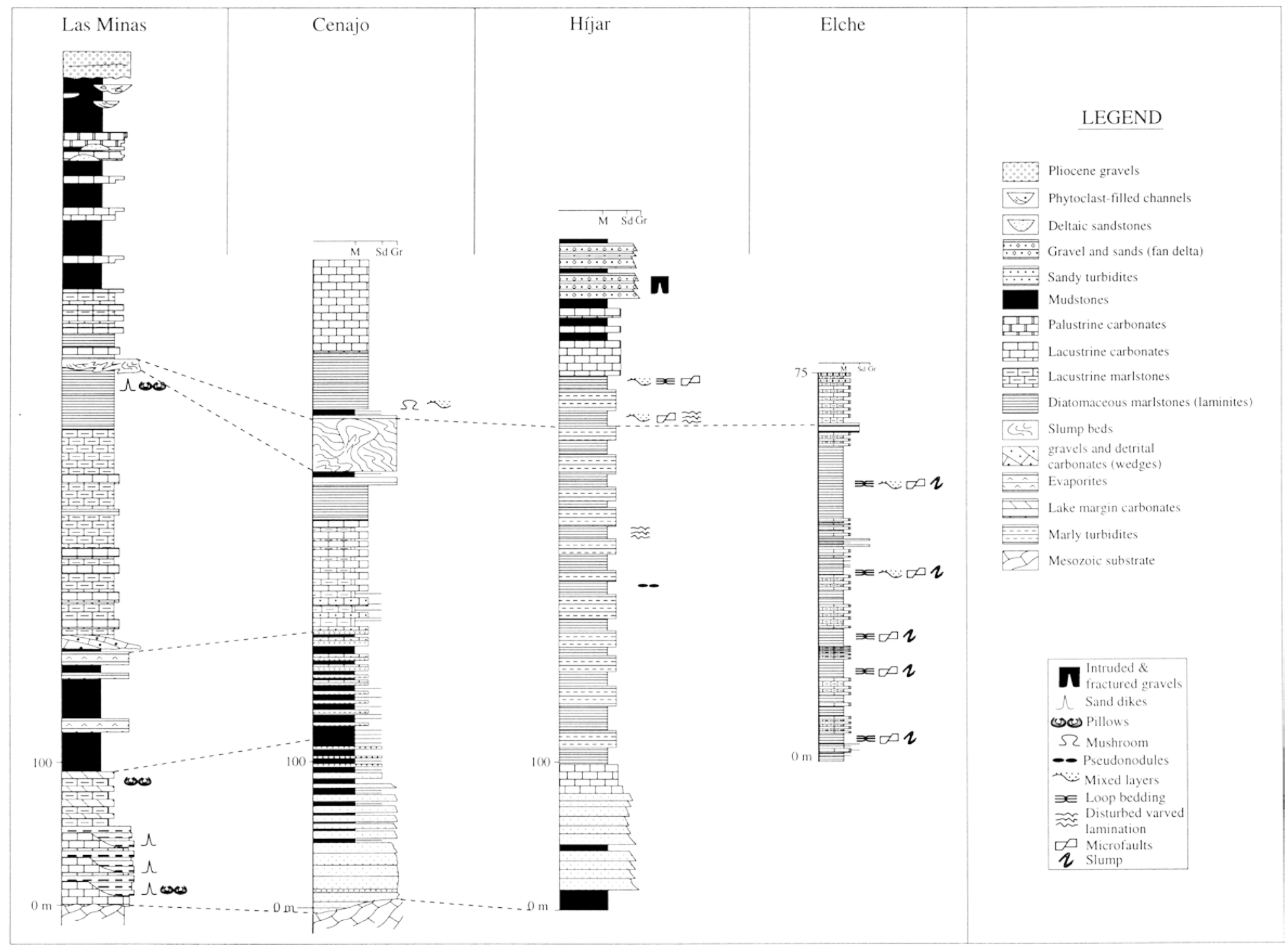

Fig. 2. Composite lithostratigraphic logs from the sedimentary fill of the Las Minas, Cenajo, Hijar and Elche de la Sierra basins. Correlation is based on the presence of some key horizons (see text). The stratigraphic sketch includes the presence of the several types of seismites recognized in the lacustrine successions filling the basins. 
the basins, i.e. Las Minas, Cenajo, Elche de la Sierra, Gallego, Hellín, show an asymmetrical tectonic pattern as a result of a higher activity of the faults, which limit the northern margins of the basins. In contrast, the Hijar Basin, located to the south of the Liétor Fault, is elongated 0101 and both the western and eastern flanks of the basin are delimited by normal faults of the same direction (Calvo et al., 1998). The characterization of the active tectonic stress field of the region from Miocene to Recent has been carried out by means of kinematic and dynamic analysis (Martín Velázquez et al., 1998; Rodríguez-Pascua, 1998). Two main suborthogonal stress fields, one indicative of NW-SE shortening (Fig. 1C) and the other one related to NE-SW tensional stresses (Fig. 1D), have been determined. The former was responsible for the emplacement of the Cazorla-Alcaraz Arc whilst the latter accounted for the development of normal and/or strike faults resulting in the formation of the lake basins. Similar results were obtained from seismological analysis of the region (Rodríguez-Pascua, 1998), which provides evidence that both the orientation of the major axis of the paleostress ellipse in the horizontal plane $\left(u_{\text {HAMX }}\right)$ of the area has not changed basically from Late Miocene to Recent.

\section{Sedimentology of the lacustrine deposits}

The sedimentary fill of the several continental basins extended in the area shows a basic similar pattern although the basins were geologically unconnected. The similarities in the vertical evolution of the lacustrine facies are very clear in the Cenajo and Las Minas basins. Comparison between the stratigraphic successions of the two basins (Fig. 2) is favoured by the presence of correlative beds. Thus, an evaporite unit comprising gypsum deposits that contain native sulphur is recognized in the two sections; moreover, a large-scale set of slump beds is observable at a similar stratigraphic level. The latter feature has been interpreted previously as a result of a high-magnitude seismic event probably related to the extrusion of lamproitic volcanic rocks, dated at $5.7 \wedge 0.3 \mathrm{Ma}$, in the region (Bellon et al., 1981; Elizaga and Calvo, 1988). None of these features occur in the remaining basins (Elche de la Sierra, Hijar, Gallego) but the sedimentary fills of these basins show also similarities regarding both thickness and, above all, trend in the evolutionary facies pattern (Elizaga, 1994).

As observed in the Cenajo and Hijar basins, the first stages of sedimentation were characterized by sedimentation of clastic deposits in fan-deltas and/or short fluvial systems with their heads encroached in Mesozoic reliefs. In the Cenajo Basin, the fan-delta deposits evolved distally into turbidites. In the Híjar Basin, the fluvial sediments are progressively interbedded with palustrine/shallow lacustrine marlstone and carbonate deposits. The lowermost deposits that crop out in the Las Minas Basin comprise detrital carbonates (turbidites) related to resedimentation from shallow carbonate platforms. Further progressive enlargement of the lake facies in all basins is recorded by marlstone and carbonate deposits, with intervening gypsum in the Las Minas and Cenajo basins. These facies, which are representative of an episode of relative lake lowstand, are overlain by a thick package of alternating laminated carbonates and marls (Fig. 2). The laminated, varve-like marls contain abundant planktonic diatoms and siliceous sponges spicules, which allows their commercial use as diatomite (Calvo and Elizaga, 1987). Intercalations of carbonate turbidites within the laminated marls are frequent, especially in the narrower and smaller basins such as those of Elche de la Sierra and Hijar. In the latter basin, calcareous turbidites can account for up to $70 \%$ of the total thickness of the carbonate-marl association (Calvo et al., 1998). These facies characterize and episode of generalized deepening of the lake basins, the higher depth allowing stratification of the water column and further preservation of the laminated structure of the sediments at the bottom lake.

In the Las Minas and Cenajo basins, this thick monotonous succession of deeper lake deposits includes a slump deposit formed of a set, up to $40 \mathrm{~m}$ thick, of contorted and fractured marlstone and limestone beds. As commented above, this event is tentatively related to seismic activity associated with volcanism and caused breakdown of the older sediments accumulated in platform and/or basinal areas of the lakes. The large-scale slump deposit is covered by a monotonous succession of alternating diatomaceous marlstone and limestone deposited at moderate depth in open lake areas (Bellanca et al., 1989). This succession is also recognized in the other basins, where 

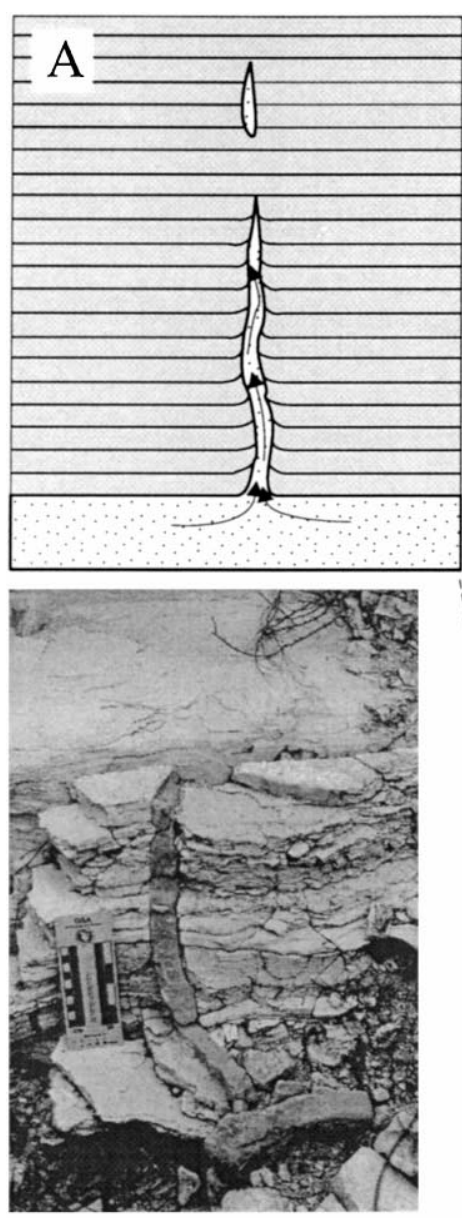
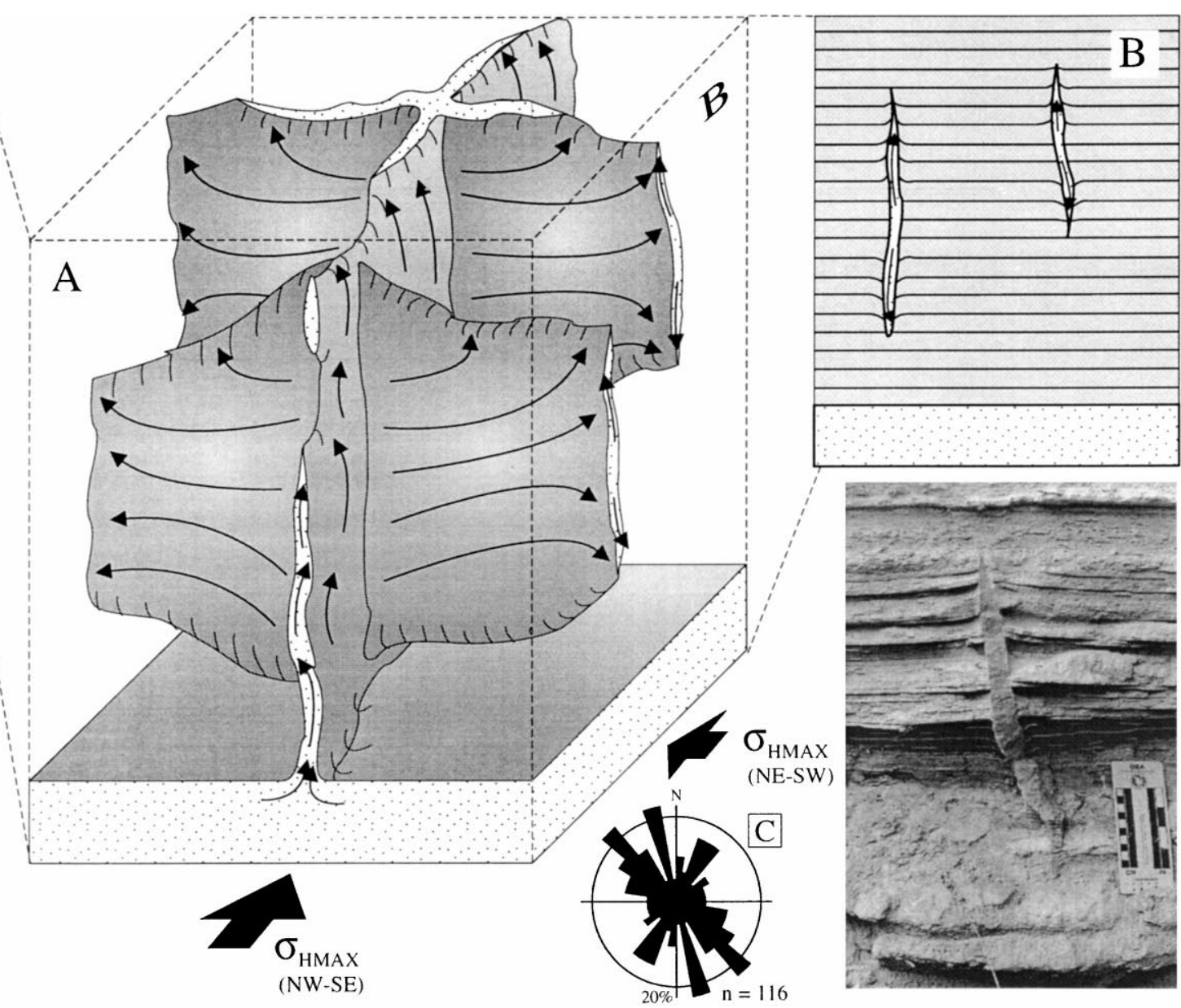

Fig. 3. Composite sketch showing the pattern of formation of sand dikes related to seismic shocks. Upward movement of the sand, intruding NW-SE planes, originates from liquefaction of a basal sand bed; subordinate dikes intruding NE-SW planes formed by lateral sand flow. Insets A and B illustrate the morphologies of the major and subordinates

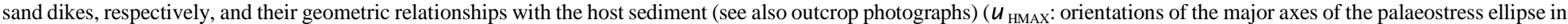
the horizontal plane). Inset $C$ shows the rose diagram resulting from plotting on a stereo net of $116(n)$ measurements of orientations of both major and subordinate dikes. 
however the sedimentary breakage represented by the slump deposit is not recorded.

The Miocene section ends with shallow-lake carbonate beds in the Cenajo Basin whilst in other basins, such as in Hijjar and Elche de la Sierra, the marlstones and limestones pass upward progressively into terrigenous fan-delta facies (Fig. 2). This pattern is somewhat different in the northern part of the Las Minas Basin, where the Miocene section is capped by a mixed clastic-carbonate unit along the footwall of a major fault that limits the basin margin (Calvo et al., 2000).

The deformational structures interpreted as seismites are present at several levels across the stratigraphic sections recognized in the different basins (Fig. 2). The seismites occur in both marginal, shallow-lake facies and deeper, open lake deposits which characterize the sedimentary evolution of the lake basins described above.

\section{Description and interpretation of seismites}

Soft-sediment deformation structures occur in a large variety of morphologies in the stratigraphic record; this variety has resulted in a large number of descriptive terms, which often makes difficult their comparison with other deformational structures. Moreover, similar deformational structures have been interpreted in an opposite way, i.e. caused by purely depositional processes (Anketell et al., 1970) versus induced by seismic shocks (Alfaro et al., 1997). In the study area, we have tried to group the observed deformational structures into eight basic types, which are described and interpreted as follows.

\subsection{Sand dikes}

This structure consists typically of sand-filled linear fractures in cross-section that can range from tens of centimetres to several metres in vertical extent (Audemard and De Santis, 1991; Obermaier et al., 1993); the sand-filled fractures are commonly rooted in a sand bed and cut confining horizons of distinct lithologies. Yet clastic dikes showing irregular morphologies and downward thinning have also been documented (Martel and Gibling, 1993). In the lacustrine formations of the Prebetic area, sand dikes are recognized at several levels of the stratigraphic succession, espe- cially in the Las Minas Basin (Fig. 2). The dikes, ranging from $2 \mathrm{~cm}$ wide and $30 \mathrm{~cm}$ deep (penetration depth, measured vertically) to $21 \mathrm{~cm}$ wide and $200 \mathrm{~cm}$ long, intrude layered calcareous siltstone and marlstone (Fig. 3). A network of dikes formed of major sand intrusions with laterally linked dikes is commonly observed (Fig. 3). The major dikes bend the intruded layers upward whilst layers crossed by the subordinate dikes display opposite bending directions (Fig. 3). The dike fills comprise homogeneous medium- to coarse-grained carbonate sand of the same nature as the beds from which the dikes project upward. Dikes are straight to somewhat sinuous in plan view. Sand volcanoes have not been clearly recognized at the top of the dikes although thickening of the sand at the top of the dikes is common. They are distributed according to two main directions: 1501 (major dikes) and 601 (subordinate), this is, exactly perpendicular (Fig. 3). In most cases, dikes are vertical in cross-section.

Interpretation: The carbonate sand fill intruded layered, finer-grained sediments that behaved as a confining bed. Upward movement of the sand is supported by the fact that the major dikes are rooted in a basal sand bed and the sand dike bend the confining layers upward. In contrast, the subordinate dikes resulted from lateral flow of the sand perpendicular to the major dikes (Fig. 3). The origin of dikes was ultimately related to liquefaction of the basal saturated sand bed, possibly triggered by seismic shocks (Audemard and De Santis, 1991; Obermaier et al., 1993). Our observations and the proposed model of formation of the sand dikes is clearly different from that deduced for other reported clastic dikes, for instance, those of the Devono-Carboniferous Horton Bluff Formation of Nova Scotia (Martel and Gibling, 1993); therein, the dikes are irregular and thin downward, and they are associated with wave-dominated shoreline lacustrine deposits. Martel and Gibling (1993) interpreted the sand injections as caused by pressure waves.

\subsection{Intruded and fractured gravels}

This deformational structure, developed in coarsegrained clastic deposits, consists of irregularly shaped dikes made of gravel with variable amount of sand, which intrude overlying sediments (Obermaier et al., 


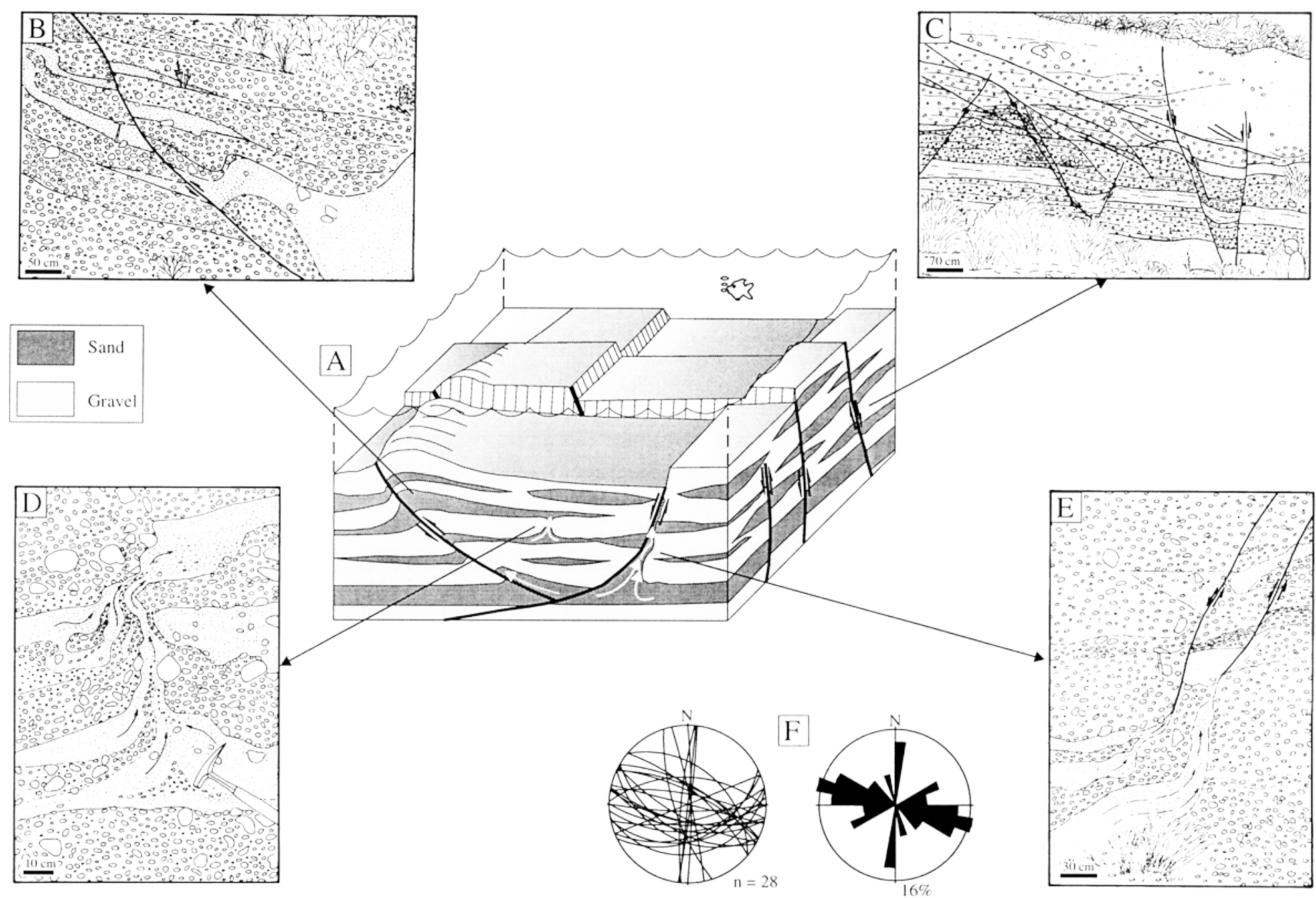

Fig. 4. Composite sketch showing the pattern of formation of intruded and fractured gravels. (A) Idealized block diagram showing the effect of cyclic shear stress derived from seismic shock in a sedimentary sequence made of interbedded gravel and sand. The white arrows indicate upward movement of liquefied sand and gravel that in many cases is favoured by the formation of fracture planes. Insets B, C, D and E correspond to line drawings from outcrop photographs; (B) reverse fault, (C) normal faults, (D) narrow antiform due to violent scaping of liquefied sand and gravel, (E) same structure as in (D) but associated with normal faults. Inset F shows the stereo net projection of the plane directions determined in fracture planes and narrow antiforms and its derived rose diagram ( $n=$ number of measurements). 


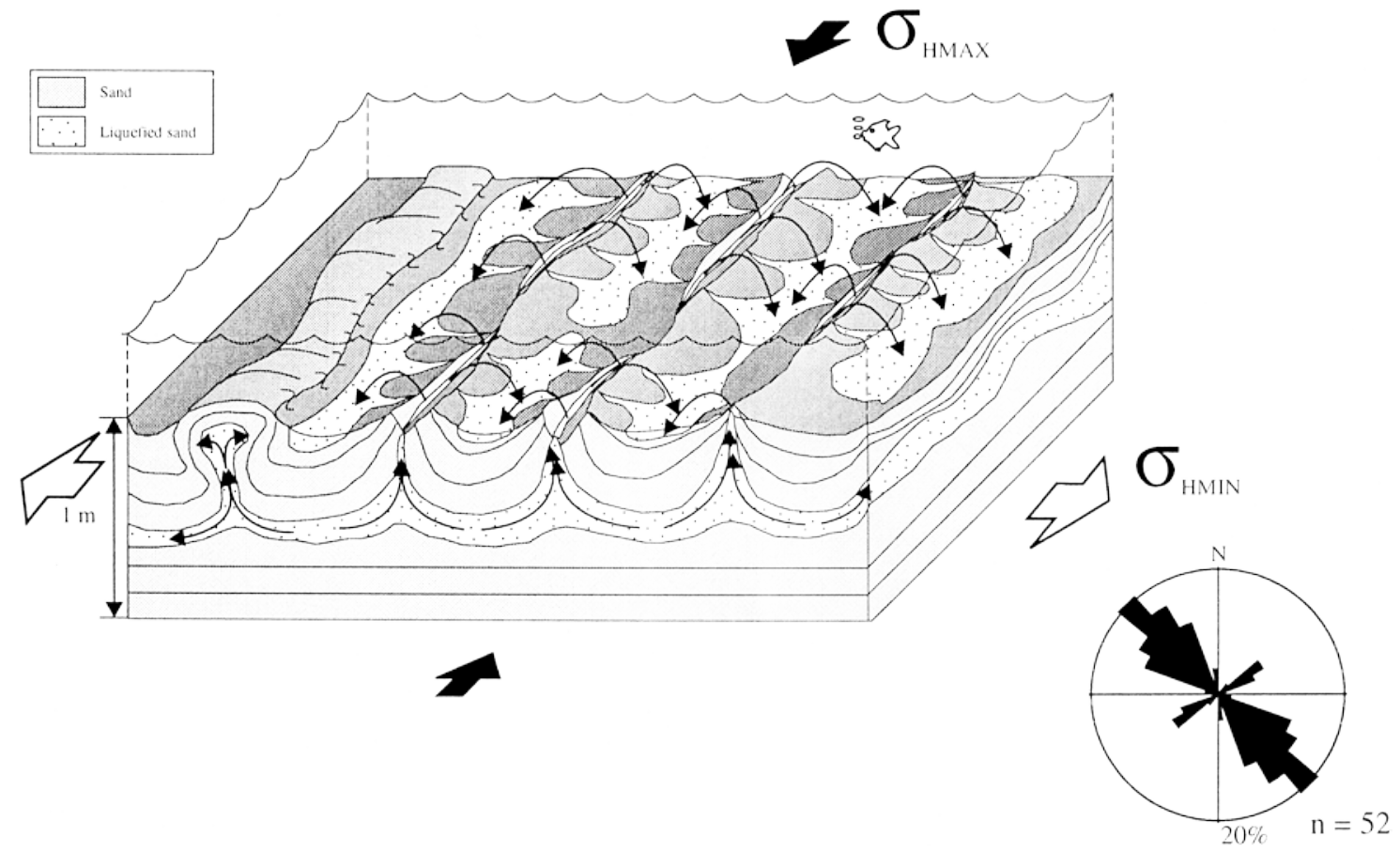

Fig. 5. Idealized sketch showing the pattern of formation of pillow structures. In the drawing, a clear differentiation is made among the sand layer subjected to liquefaction, the underlaying sand layers (undisturbed) and the folded overlying sand (pillows) formed as a result of fluidization (upward flow) of the sand particles. $u_{\text {HMAX }}$ (maximum compression) and $u_{\text {HMIN }}$ (maximum strength) indicate the horizontal projections of the major axes of the palaeostress ellipse in the horizontal plane as deduced from the accompanying rose diagram and calculated by brittle deformation tectonic analysis.

1993). Contacts between the intruding clastics and the host sediment are commonly sharp resulting in a fractured appearance of the deposit. In the lacustrine deposits of the Prebetic area, the occurrence of this structure is restricted to the uppermost part of the section in the Hijar Basin (Fig. 2). The deformation affects gravels and sands deposited in a subaqueous fan delta environment (Jiménez Sánchez, 1997). The beds are characterized by the presence of narrow antiforms and associated fractures through which underlying gravel and sand beds intrude upward up to $1.5 \mathrm{~m}$ (Fig. 4). The fractures are both normal and reverse faults. These faults are distributed according to two main directions: 1101 (predominant, always corresponding to normal fracture planes) and 101 (subordinate) (Fig. 4).

Interpretation: In view of its depositional setting, the sediment was obviously water-saturated when the deformation took place. Under these conditions, the liquefaction and $\mathrm{fl}$ ion of the gravels and sands took place in absence of a confi bed. Wide development of fractures (both normal and reverse; Fig. 4) is interpreted to derive from the low susceptibility of the coarse-grained deposit to liquefaction (Guiraud and Plaziat, 1993). As pointed out by these authors, the magnitudes of the earthquakes inducing the formation of this type of deformational structure are necessarily high (see discussion below). Under this assumption, the intruded and fractured gravels reflect deformation under both brittle and ductile conditions triggered by strong seismic shocks.

\subsection{Pillow structures}

These structures consist of a suite of deformed, concave upward bodies (pillows) made of silts and sands whose original layering bent round parallel to 
the basal surface and is truncated at the top surface (Pettijohn and Potter, 1964; Sims, 1975; Davenport and Ringrose, 1987). This type of structure is present mainly in the Las Minas Basin where it has been recognized in distinct stratigraphic positions (Fig. 2 ). The pillows occur at rather regular intervals across single-layered sand beds forming a series of laterally connected synforms and antiforms (Fig. 5); the width of the synforms ranges from 30 to $150 \mathrm{~cm}$ and the height of the deformed beds ranges from 30 to $80 \mathrm{~cm}$. The sediment included in the pillows is typically medium- to coarse-grained sand arranged in layers of variable grain size. The layered internal structure is lost in the sandy horizon below the pillows. The top surface of the pillow beds is commonly truncated; in a few places, an alignment of extruded sand coincident with the axes of the tight antiforms is observed, which is quite similar to that described by Montenat et al. (1987) in sediments affected by seismic shaking from the Neogene formations of SE Spain. In plan view, the axes of the pillows are distributed according to two main directions: 1501 (predominant) and 0601 (subordinate).

Interpretation: Pillows and other similar deformation structures, e.g. ball-and-pillow, pseudonules, load casts (Allen, 1982), have been interpreted commonly as related to load of denser sediment in a two-layer system. The causes for load-induced deformation may be varied, i.e. rapid sediment accumulation enhancing differential compaction, stress induced by the action of large waves, vertical stress due to ice growth in glaciogenic sediments, etc. (Ricci Lucchi, 1995). Moreover, a seismic origin for pillow structures has been also invoked (Montenat et al., 1987; Cojan and Thiry, 1992; Guiraud and Plaziat, 1993). We postulate that the pillow structures recognized in the lacustrine deposits of the Prebetic area were seismically induced as the sediments in which they are present do not show significant density variations and they are not covered by lithologies that could cause sudden overloading. The formation of the pillows was initiated by the liquefaction of some definite layers within packages of layered sands (Fig. 5) that were forced to fold as a result of upward flow of the liquefied sand at more or less regularly spaced sites. The resulting pillow structures are similar to those obtained experimentally by Owen (1996) at sand-sand interfaces subjected to shaking.

\subsection{Pseudonodules}

In the study area, pseudonodules, a type of deformational structure consisting of isolated masses of sediment of various morphologies (saucer-like, detached pillows, bolsters, etc.) embedded in an underlying deposit of contrasted density (Allen, 1982), are present in marlstone facies alternating with laminites. They have been recognized only in one bed of the lithostratigraphic section of the Hijar Basin (Fig. 2). Therein, the pseudonodules occur as a single, laterally extensive row of $1 \mathrm{~cm}$-thick, white diatomaceous marlstone bodies which are interspersed with denser marlstone at the top of a turbidite bed in turn covered by laminites (Fig. 6). The pseudonules are very irregular resembling the drop and sag structures described by Stewart (1963), but in that case the sunk interspersed masses are made of high-density (heavy minerals) sediment.

Interpretation: The formation of pseudonodules was investigated experimentally by Kuenen (1958), who simulated the deformational behaviour of sands overlying clays under the effect of shaking. In these conditions, the more dense sands sank into the clays as individualized, variously shaped masses. The pseudonodules present in Híjar are, in contrast, formed of diatomaceous marl, a sediment possessing lower density than the turbidite marlstone in which the pseudonodules are enclosed. From this point of view, the pseudonodules described here are genetically different to detached pillows. This may be explained by the fact that, under seismic shaking, liquefaction of the turbidite marlstone decreases drastically its bulk density and shear strength allowing sinking of the overlying diatomaceous layer. Although yet poorly documented, liquefaction of cohesive, fine-grained carbonate has been described previosly by Pratt (1998) in ancient lacustrine deposits.

\subsection{Mushroom-like silts protruding into laminites}

This structure consists of small diapir-like morphologies made of silt-size sediment, which intrudes and deforms overlying laminites (Fig. 7). Similar deformational structures, typically displaying a mushroom shape, have been described by Hempton and Dewey (1983), Scott and Price (1988) and Alfaro et al. (1995). They have been recognized in several 


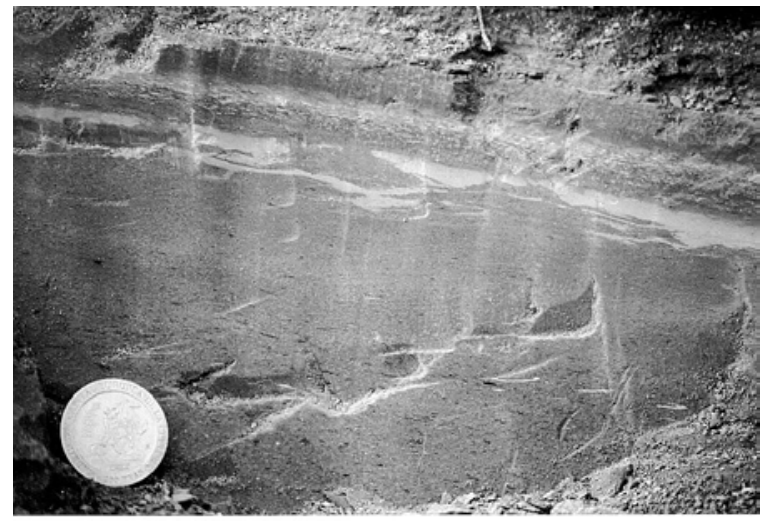

Fig. 6. Close-up view of pseudonodules (white irregular masses) located toward the top of a marlstone turbidite bed in the stratigraphic succession of the Híjar Basin. The top of the marlstone is covered by diatomaceous laminites. Coin for scale is $2.4 \mathrm{~cm}$ in diameter.

horizons toward the upper part of the lacustrine succession of the Cenajo Basin (Fig. 2). The mushroom-like structures are present at a horizontal spacing of 10-15 cm throughout the beds and show width ranging from 1 to $2 \mathrm{~cm}$ and height up to $0.5 \mathrm{~cm}$. Incipient doming of the silts at the contact with the overlying laminites is locally observed. In plan view, the protruding into silts are seen as linear to slightly sinuous ridges, which locally open into separate branches (Fig. 8). Measured orientations of the ridges indicate a predominant NE-SW direction, locally parallel to $u_{\text {HMAX }} \mathrm{NE}-\mathrm{SW}$.

Interpretation: The laminite sequence covering the silt behaved as a confining bed because of its low susceptibility for liquefaction. This is in contrast with the higher liquefaction potential of the silt which, as observed under SEM, displays a highly disorganized internal structure made of both broken and complete diatom frustules, calcite and aragonite crystals, and scattered clay particles (Calvo et al., 1998). The liquefaction of silts, triggered by seismic shock, resulted in the upward flow of the silt particles pushing the laminites (Fig. 8A and B) that were deformed plastically. A genetic relationship, i.e. deformation induced by the same seismic event, between the mushroom structure and overlying folded set of lamine (mixed layer) (Fig. 7) could be postulated in view of the proximity of the two deformational structures and the fact that the laminae

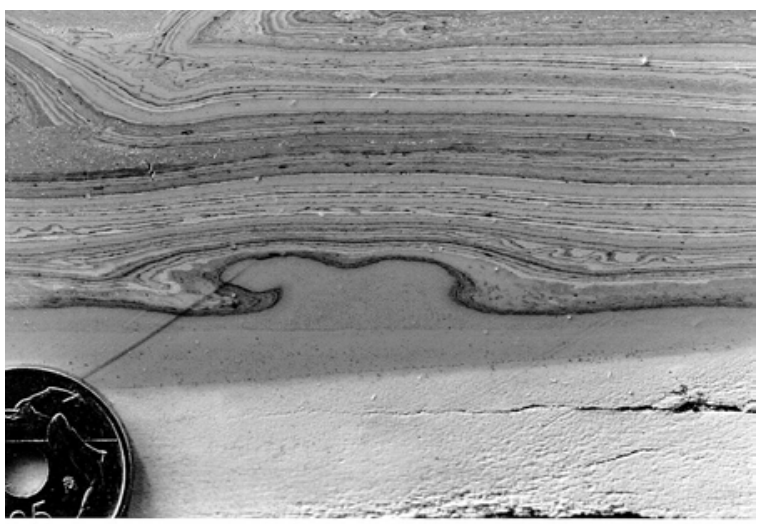

Fig. 7. Close-up view of a mushroom-shaped structure due to silts protruding into laminites. Note small-scale folding of the laminites aside the convex-up structure. Large folds at the upper part of the photograph could be also related to the same seismic shock that induced the formation of the mushroom-like structure (see text).

probably remained unlithified. This latter assessment is supported by the commonly observed great thickness (up to $15 \mathrm{~cm}$ ) of the mixed layer structures.

\subsection{Mixed layers}

The term "mixed layer", used first by Marco and Agnon (1995), refers to beds that show a gradual upward transition from folded layers grading into fragment-supported and matrix-supported textures between undeformed beds, whose origin is related to the activity of synchronous faults due to moderate to high magnitude seismic shocks. Examples of mixed layers have been observed at several levels of the Upper Miocene succession in Hijar, Cenajo and Elche de la Sierra basins. They are associated typically with varve-like, laminite units in which four horizons are differentiated from bottom to top (Fig. 9) (i) basal undisturbed laminite bed, (ii) folded laminites, (iii) fractured and fragmented laminites, and (iv) graded layer from fragment-supported to matrixsupported texture. Fragments made of single and/or sets of laminites are several millimetres long. The thickness of the sequence of mixed layer and its folded lower contact ranges from 4 to $10 \mathrm{~cm}$. The top of the mixed layer is overlain sharply by horizontally laminated sediment.

Interpretation: The transition from undisturbed laminites to folded and fractured layers ending with 


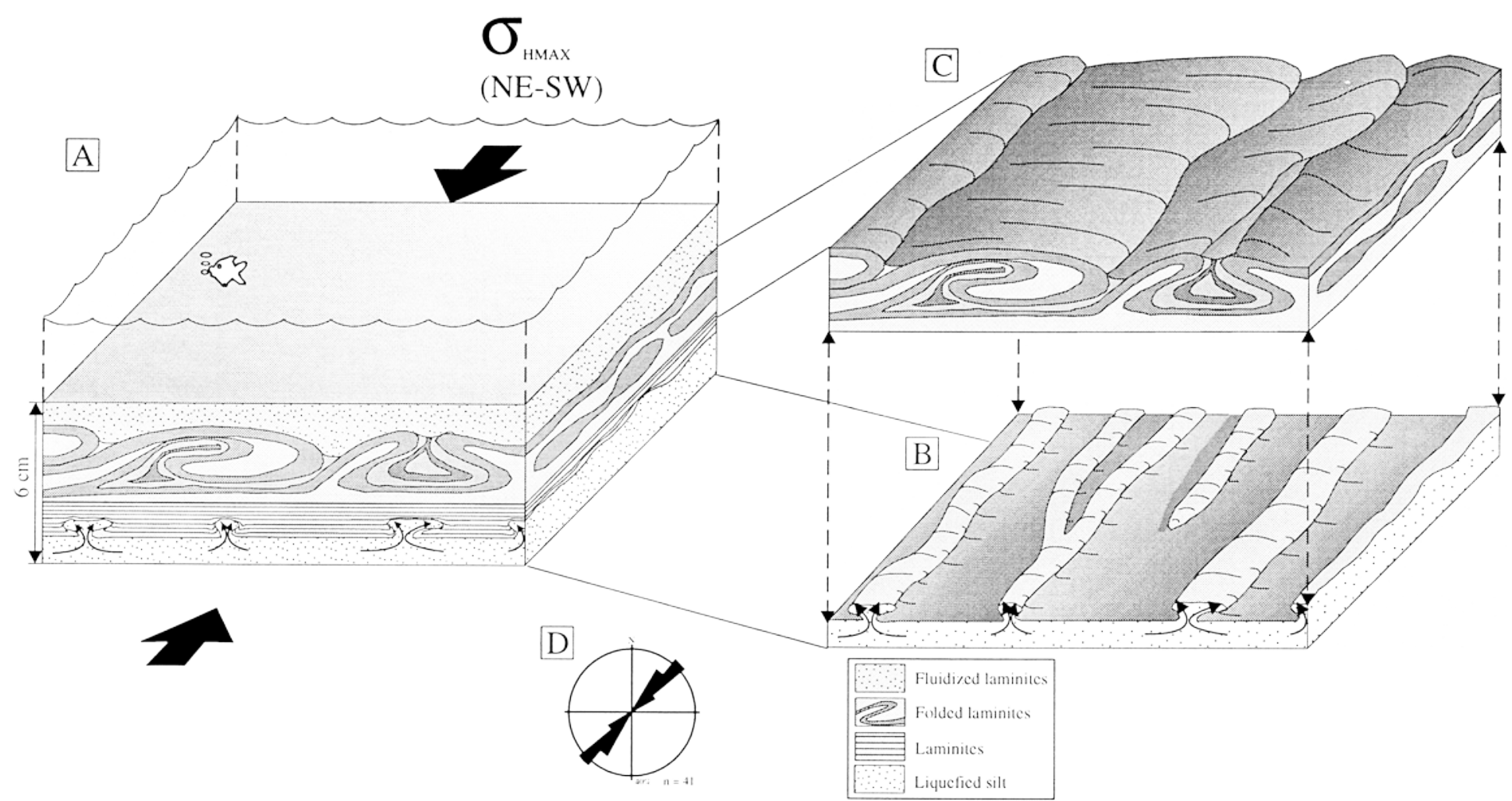

Fig. 8. Idealized sketch showing the pattern of formation of mushroom-like silts protruding into laminites. (A) Block diagram showing superposition of folded and fluidized laminites (interpreted as mixed-layers) over mushroom-shaped structures ( $u_{\text {HMAx }}$ orientation of the major axe of the palaeostress ellipse in the horizontal plane). (B) Plant view of the mushroom-like silts protruding into laminites showing local opening of the ridges into separate branches. (C) Folded laminite sequence corresponding to the lower part of a mixed-layer structure that probably was related genetically to the formation of the mushroom-like structures. 


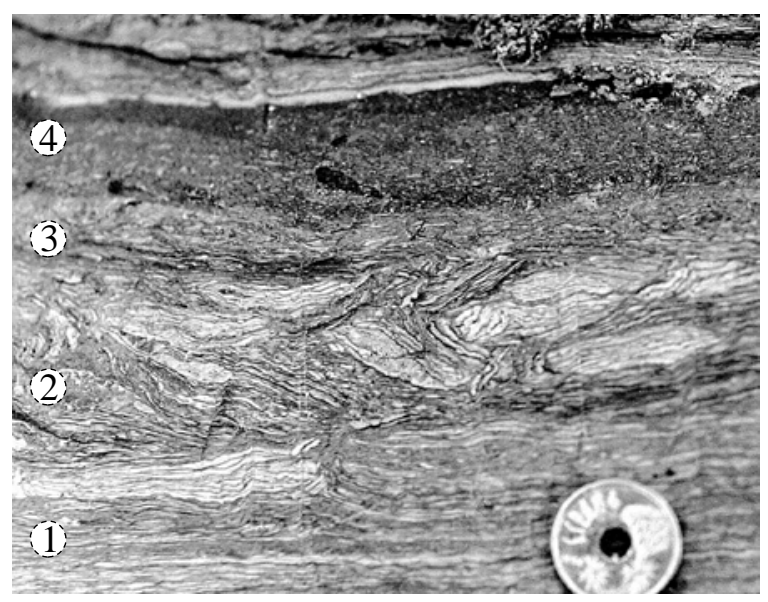

Fig. 9. Close-up view of a laminites showing a completely developed mixed layer structure. Horizons 1, 2, 3 and 4 correspond to undisturbed, folded, fractured and graded units of the mixed layer sequence, respectively. Coin for scale is $2 \mathrm{~cm}$ in diameter.

a clastic-textured sediment suggests that the deformation, which is assumed to be caused by seismic shock, affected differentially the laminated sediment from top to bottom (Fig. 10). In a first stage, strain forced the unconsolidated or poorly lithified laminae to fold; after the earthquake continued, folding migrated downward and simultaneously the increased shear-stress resulted in fracturing of the upper folded laminae. The top of the cohesive sediment was fluidized and resuspended, the laminites being ruptured and then settled out. Negligible transport of the laminite fragments is supported by the fact that, in many cases, the lower fragments can be restored to their original place in the underlying layers

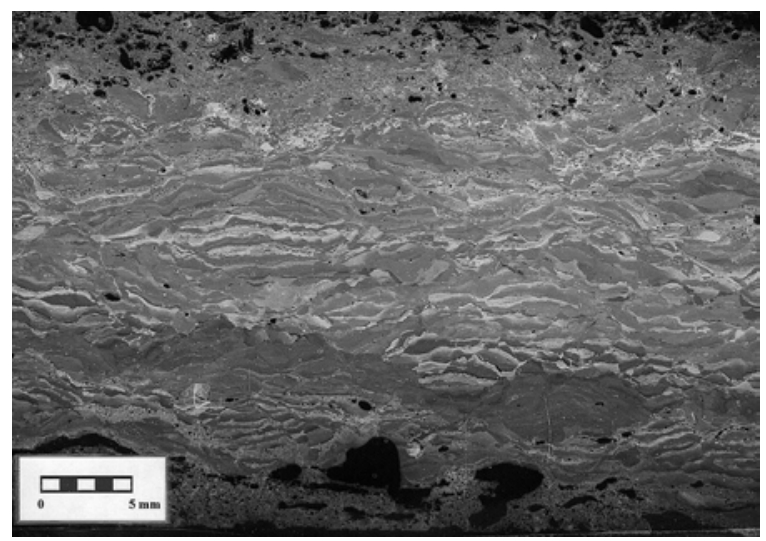

Fig. 11. Photomicrograph of disturbed varved lamination.

(Marco and Agnon, 1995). In agreement with these observations, the sequence showing "mixed layer" can be interpreted as a result of a single seismic event promoting downward migration of the deformation through a cohesive sediment. Locally, the mixed layer sequence occurs partly developed lacking the fluidized upper unit. This may be explained by the fact that the earthquake magnitude did not exceed the limit needed to fluidize the laminite sediment (Marco and Agnon, 1995).

\subsection{Disturbed varved lamination}

This structure, typically developed in laminite sequences, consists of packages of diatomite laminae that display irregular thinning and thickening without losing their lateral geometric continuity (Fig. 11). The disorganization of the laminae is recognized both in
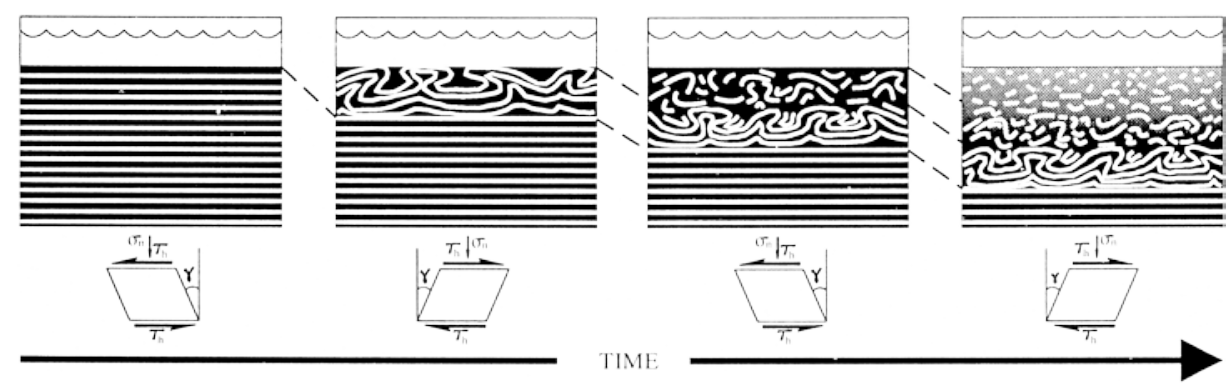

Fig. 10. Sketch showing the evolution of the deformation of a laminite sequence subjected to continuous seismic shock, finally resulting in a complete mixed layer structure. Cyclic shear stress throughout the duration of the earthquake is represented beneath the cartoons; $\sigma_{n}$, vertical stress; $\pi_{n}$, tangential shear; $\gamma$, shear strain. 


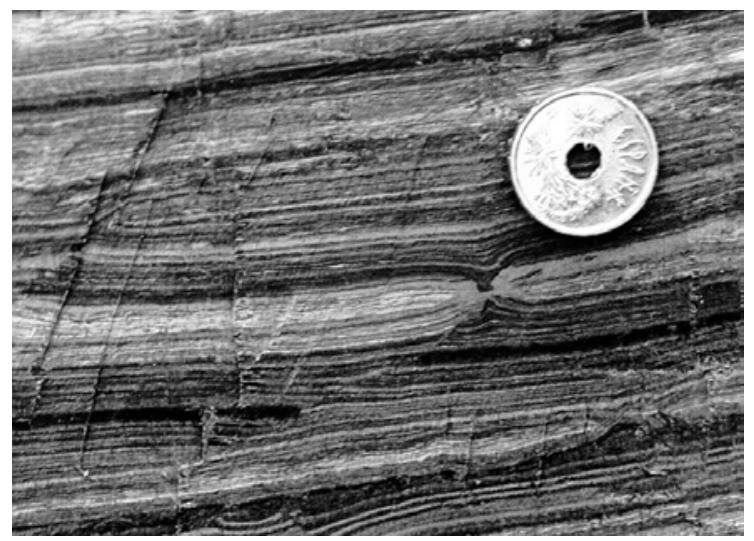

Fig. 12. Close-up view of loop bedding in diatomaceous laminites; note the boudinage-like morphology shown by this structure characteristic of ductile deformation. Coin diameter is $2 \mathrm{~cm}$.

outcrop and thin-section. Some micro-faults are locally observed within the laminites. Thickness of the disturbed lamine ranges from 1 to $5 \mathrm{~cm}$ with minor change along the single beds. This type of deformational structure has been recognized mainly in the lacustrine succession of the Hijar Basin (Fig. 2).

Interpretation: Thinning and thickenning of the laminae reflect ductile deformation, which in turn coexisted with a ductile-brittle behaviour of the sediment as evidenced by the development of low-angle normal micro-faulting. We interpret that the deformation was related to continuous, slow punctuated movement of the faults limiting the basin, this resulting in micro-seismic shocks of higher magnitude than those caused loop bedding in laminites (see discussion below). Alteration of the laminae by burrowing can be ruled out as the sediment accumulated under anoxic conditions on the lake bottom.

\subsection{Loop bedding}

Loop bedding consists of bundles of laminae that are sharply constricted at intervals, giving a morphology of loops or links of a chain (Fig. 12) (Calvo et al., 1998). This structure has been documented mainly from lacustrine finely laminated sediments of several ages (Cole and Picard, 1975; Gibling et al., 1985; Trewin, 1986). In the study area, loop bedding is rather common in laminite sequences from the Hijar and Elche de la Sierra basins. In the former basin, loop bedding is especially well developed in a $1.40 \mathrm{~m}$-thick bed made of laminite packages. Four main types of loops, simple and complex loops with subcategories which embrace merely folded to microfaulted packages of laminae, have been recognized in this horizon (Calvo et al., 1998). The laminated bed overlies marlstone displaying fissures that extend up to $30 \mathrm{~cm}$ from the marlstone top downwards. The thickness of the loop bedded layers ranges typically from 8 to $15 \mathrm{~mm}$ and the loops end laterally at decimetric intervals. A sketch of the most simple type of loops, comprising bundles of laminae bending symmetrically on both sides of a boudin neck can be observed in Fig. 12. The measured orientations of the loop axes are distributed according to two main directions: 0051 (predominant) and 1051 (subordinate), this is, quasiperpendicular. These orientations measured in laminite sequences of the Híjar Basin are quite similar to those measured in the laminites from the Elche de la Sierra Basin. On the other hand, the orientations of the fissure planes in the marlstone bed below the laminites in Hijar show a similar pattern with two main modes (3501 and 1001) (Calvo et al., 1998).

Interpretation: Loop bedding in laminite sequences of the Hijar and Elche de la Sierra basins is interpreted as a result of the stretching of unlithified to progressively more lithified laminated sediments in response to successive minor seismic shocks, ultimately related to the slow movement of extensional faults. The several types of loops reflect a distinct deformational behaviour of the laminite sequences as the lithification progressed (Calvo et al., 1998), varying from purely ductile to purely brittle deformation. Consistent directions determined both for loop axes and fissures developed in marlstone beds underlying the laminites, that in addition are similar to those of the main faults that limit the basins, strongly suggest a common tectonic origin of the deformation.

Besides the aforementioned deformational structures, slump beds occur in the lacustrine formations of the Prebetic Zone at very different scales (from a few millimetres thick packages of laminites to tens of metres thick sets of contorted and fractured diatomaceous beds) (Fig. 2). In the present study about seismites in lacustrine sediments we have not included these structures because of their accurate interpretation as seismically induced is commonly seen as highly problematic (Allen, 1982; Ricci Lucchi, 


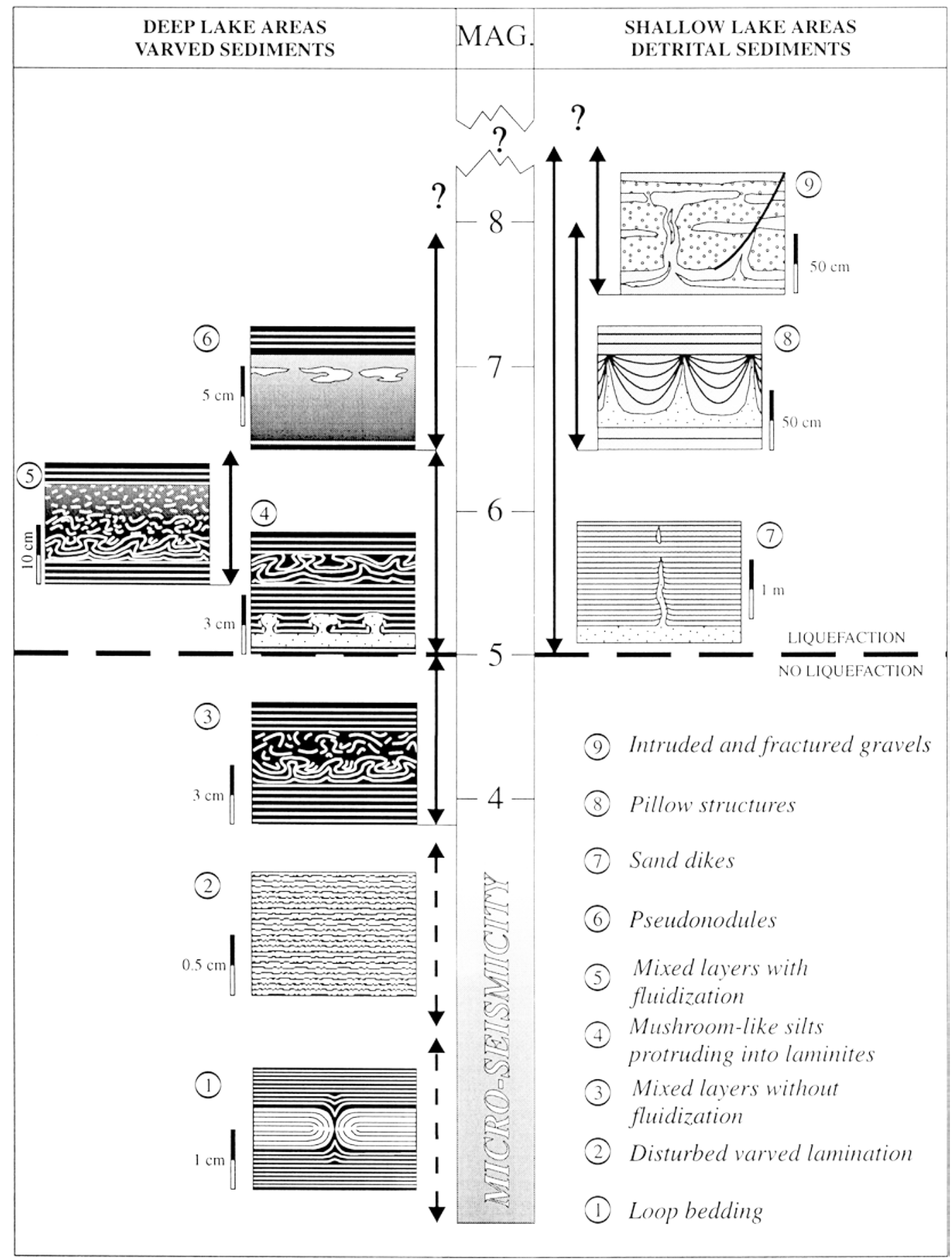

Fig. 13. Summarized sketch of the several seismite types recognized in the Upper lacustrine formations of the Prebetic Zone with indication of the rank of earthquake magnitudes at which the different seismites are interpreted to form. Lower limit (M5) for liquefaction is based on Atkinson (1984). Seismites occurring in deep and shallow lake deposits are sketched in separate columns in view of their physical properties and further distinctive response to deformation under seismic shock. 
1995). In fact, a number of tectonic and/or sedimentary processes, i.e. external drag of overflowing masses, tilting of platforms by sediment overloading, earthquakes, and others causing modification of tangential stresses on slopes, can be involved in the formation of slumps. Despite the common unascertainity for the interpretation of slumps, the occurrence of some extremely large-scale slump beds (up to $40 \mathrm{~m}$ thick) in the studied formations strongly suggests that they could be triggered by high energy (in terms of earthquake magnitude) seismic shocks.

\section{Discussion}

\subsection{Earthquake magnitudes}

The interpretation of seismites in terms of the magnitudes of the earthquakes that induced their formation has generated a considerable literature (Sims, 1975; Hempton and Dewey, 1983; Allen, 1986; Audemard and De Santis, 1991; Cojan and Thiry, 1992; Guiraud and Plaziat, 1993; Obermaier et al., 1993; Marco and Agnon, 1995 amongst others). Allen (1986) proposed a theoretical approach to the relationships between earthquake magnitudes, epicentral distances and occurrences of soft-deformation structures at a basinal scale. In this chapter, we are just concerned with the estimation of the magnitude values of the earthquakes that induced the formation of the seismites recognized in the Upper Miocene lacustrine formations of the Prebetic area.

The soft-sediment deformation structures that we interpret as seismites have been ordered according to a rank of earthquake magnitudes (Fig. 13). The effect of seismic shocks is distinctively recorded within sediments of deep lake environments and those formed in shallow marginal lake areas as the deposits show different physical properties, i.e. distinct response to pore fluid pressure related to variable grain-size, and consequently distinct susceptibility to deformation driven in most cases by liquefaction and fluidization processes (Owen, 1996). We assume previous statement by Atkinson (1984) who considers M5 as the lowest magnitude which contributes to the probability of liquefaction because earthquakes of magnitude less than 5 are not of sufficient duration to cause liquefaction, a statement also confirmed by Audemard and De Santis (1991).

Deep lacustrine facies consist mainly of diatomaceous, varve-like laminated sediments and marlstone turbidites. The diatom-rich laminites are characterized by high cohesion, high natural shear strength and high sensitivity (Grimm and Orange, 1997), making the laminites prone to extensive brittle, plastic and/or fluid deformation when subjected to some kind of mechanical deformation. Keeping in mind these physical characteristics, shaking induced by earthquakes will affect the sediment in different manner after the magnitude of the seismic shock. Under this assumption, earthquakes of low magnitude related to small movement of faults result in ductile to brittle deformation as recorded by loop-bedded laminite sequences (Calvo et al., 1998) (Fig. 13). Disturbed varved lamination requires slightly higher magnitudes to form as the deformation does not imply purely stretching of the laminae but also disorganization under tensile, deep-seated tectonic stresses. At higher earthquake magnitudes, the cohesive laminites undergo ductile to brittle deformation driven essentially by vertical forces, which results in mixed layers lacking the fluidized unit. Earthquake magnitudes $2: 5$ are assumed to be necessary for triggering liquefaction of laminite sequences in view of the results obtained by Marco and Agnon (1995). These authors deduced that mixed layers showing fluidized sediment developed in varve-like laminites from the Lisan Fm were caused by at least M5.5 earthquakes. The liquefaction of marlstone interbedded with laminites resulting in mushroom-like structures could take place at slightly lower earthquake magnitudes ( $M$ 2:: 5, Hempton and Dewey, 1983). Pseudonodules, a classical deformational structure analyzed in detail by Kuenen (1958), would require, according to this author, earthquake magnitudes probably exceeding 6.5 for their formation.

Seismites recognized within shallow lake deposits have been interpreted in all cases as resulting from liquefaction of coarser-grained (sands, locally gravels), less cohesive deposits where natural shear strength is considerably reduced by comparison with the laminites and associated sediments. Sand dikes occurring in lacustrine and fluvial deposits have been interpreted as related to earthquakes of magnitudes ranging from 5 to 8 (Audemard and De Santis, 
1991; Obermaier et al., 1993). A rather similar rank of earthquake magnitudes (5.5-8) has been deduced for pillow structures developed in littoral marine, deltaic or fluvial deposits (Cojan and Thiry, 1992; Guiraud and Plaziat, 1993; Obermaier et al., 1993). Higher earthquake magnitudes are inferred for the deformation of the intruded and fractured gravels in view of the low susceptibility of these coarse-grained sediments for liquefaction (Guiraud and Plaziat, 1993; Obermaier et al., 1993) (Fig. 13).

\subsection{Relationship with the stress field of the region}

The close relationship between the described structures and the tectonic pattern of the region is supported by coincidence of the main orientation modes shown by the deformational structures and those of the major faults limiting the basins. The regional stress field that structured the area from the Late Miocene to Present is characterized by an average orientation of $\sigma_{\text {HMAX }}$ toward NW-SE, as defined by kinematic and dynamic analysis (Martín Velázquez et al., 1998; Rodríguez-Pascua, 1998). The orientations of the seismites, especially those measured in sand dikes $(n=116)$, intruded and fractured gravels $(n=28)$, pillow structures $(n=52)$, mushroom-like silts protruding into laminites $(n=$ 41) and loop bedding $(n=62)$, are systematically consistent and fall within very close fields whichever the measured deformational structure: main mode of the orientations is NW-SE and the subordinate mode NE-SW. This quasi-perpendicular distribution of the orientations reflects a radial trend of the tensional stresses that gave place to the formation of the seismites, which is in turn coincident with the regional tectonic stress field.

The control of the regional tectonic pattern on the formation of the described structures interpreted as seismites is especially marked in sand dikes, intruded and fractured gravels, and in pillow structures as they are arranged according to a network of fractures whose orientations are the same as the major faults recognized in the basins. The fractures were pathways for the intrusion of liquefied sediment during seismic shocks of $M \geq 5$. This direct relationship between the seismites and fracturing pattern produced by the earthquakes is not so clear in the more cohesive sediments of deep lake environments. Therein, the regional tectonic constrains on the formation of the seismites are demonstrated by the coincidence of the orientations of axes of bouding necks in loops and the fracture planes of mixed layers with the normal faults limiting the basins.

\section{Conclusions}

Eight basic types of deformational structures interpreted as seismites have been recognized in the Upper Miocene lacustrine formations of the Prebetic Zone, SE Spain. Structures developed in marginal lacustrine facies comprise sand dikes, pillow structures, and intruded and fractured gravels. These structures show consistent orientations (NW-SE main mode; NE-SW subordinate mode) that are coincident with the basic tectonic pattern deduced from the Late Miocene to Present in the region, this supporting the seismically induced origin of the deformational structures. Earthquakes likely affected the lacustrine sediments in two main ways. On the one hand, the seismic shocks triggered liquefaction and fluid scape processes in sediments proxy to drastic loss of shear strength when the amount of energy (in terms of earthquake magnitude) was sufficient $(M \geq 5)$. On the other, the fractures created by the earthques were pathways for the intrusion of liquefied sediment during the seismic shocks.

The uppermost value of earthquake magnitude ( $M \geq 8$ ) is inferred for the deformation of the intruded and fractured gravels in view of the low susceptibility of these coarse-grained sediments for liquefaction.

Seismites developed in deep lacustrine facies comprise loop bedding, disturbed varved lamination, mixed layers (containing or lacking fluidized sediment), mushroom-like silts protruding into laminites, and pseudonodules. Where measured, the orientations of axes and/or fracture planes in these structures are also consistent and they are similar to those of the major faults of the region. A distinction is made between seismites that resulted from folding and/or fracturing of laminite sequences under purely ductile to brittle deformation constrained by deep-seated tectonic stresses (low magnitude earthquakes related mainly to slow fault movements) and seismites that show evidence of liquefaction processes involved in 
their formation. On the basis of previous statement, a limit value of $M 5$ earthquakes is proposed for the different mechanical response of the laminites.

\section{Acknowledgements}

We thank M.B. Cita, T. Shiki and D. Gorsline for their efforts in impulsing and editing the monograph in which this paper is included. Their work in organising the Symposium on 'Sedimentary features of seismites, seismo-turbidites and tsunamiites"' developed at the 15th International Sedimentological Congress, Alicante, Spain 1998 is also acknowledged. We are also indebted to J.P. Rodríguez Aranda, S. Martín Velázquez, A.M. Alonso Zarza and S. Jiménez Sánchez who helped in field work. The content of the paper was improved by the valuable coments from Mr J. Szulc and an anonymous referee. This work has profited from the financial support of the CICYT Project AMB94-0994 and has been partly funded by a grant of the 'Consejo de Seguridad Nuclear' of Spain to one of the authors (M.A.R.P.).

\section{References}

Alfaro, P., Domenech, C., Estevez, A., Soria, J.M., 1995. Estructuras de deformación en sedimentos del Cuaternario reciente de la Cuenca del Bajo Segura (Alicante). Discusión sobre su posible origen sísmico. Geogaceta 17, 91-94.

Alfaro, P., Moretti, M., Soria, J.M., 1997. Soft-sediment deformation structures induced by earthquakes (seismites) in the pliocene lacustrine deposits (Guadix-Baza Basin, Central Betic Cordillera). Eclog. Geol. Helvet. 90, 531-540.

Allen, J.R.L., 1982. Sedimentary Structures, vol. II. Developments in Sedimentology, vol. 30B, Elsevier, Amsterdam (663pp.).

Allen, J.R.L., 1986. Earthquake magnitude-frequency, epicentral distance, and soft-sediment deformation in sedimentary basins. Sediment. Geol. 46, 67-75.

Anderson, R.Y., Dean, W.E., 1988. Lacustrine varve formation through time. Palaeogeogr. Palaeoclim. Palaeoecol. 62, 215236.

Anketell, J.M., Cegla, J., Dzulynski, S., 1970. On the deformational structures in systems with reversed density gradients. Ann. Soc. Geol. Polon. 40, 3-30.

Atkinson, G., 1984. Simple computation of liquefaction probability for seismic hazard applications. Earthquake Spectra 1, 107-123.

Audemard, F.A., De Santis, F., 1991. Survey of liquefaction structures induced by recent moderate earthquakes. Bull. Int. Assoc. Engng. Geol. 44, 5-16.

Bellanca, A., Calvo, J.P., Censi, P., Elizaga, E., Neri, R., 1989. Evolution of lacustrine diatomite carbonate cycles of Miocene age, southeastern Spain: petrology and isotope geochemistry. J. Sediment. Petrol. 59, 45-52.

Bellon, H., Bizon, G., Calvo, J.P., Elizaga, E., Gaudant, J., López Martínez, N., 1981. Le volcan du Cerro del Monagrillo (province de Murcie): âge radiométrique et corrélations avec les sediments néogènes du Bassin de Hellín (Espagne). C. R. Acad. Sci. Paris 292, 1035-1038.

Calvo, J.P., Elizaga, E., 1987. Diatomite deposits in southeastern Spain: geologic and economic aspects. Ann. Inst. Geol. Publ. Hungary 70, 537-543.

Calvo, J.P., Elizaga, E., 1994. The Cenajo and Las Minas-Camarillas basins (Miocene), southeastern Spain. In: GierlowskiKordesch, E., Kelts, K. (Eds.). Global Geological Record of Lake Basins, vol. 1. Cambridge University Press, Oxford, pp. 319-324.

Calvo, J.P., Rodríguez-Pascua, M.A., Martín-Velázquez, S., Jiménez, S., De Vicente, G., 1998. Microdeformation of lacustrine laminite sequences from Late Miocene formations of SE Spain: an interpretation of loop bedding. Sedimentology 45, 279-292.

Calvo, J.P., Gómez-Gras, D., Alonso-Zarza, A.M., JiménezSánchez, S., 2000. Architecture of a bench-type carbonate lake margin and its relation to fluvially-dominated deltas, Las Minas Basin, Upper Miocene, SE Spain. J. Sediment. Res. 70, 240-254.

Cita, M.B., Ricci Lucchi, F. (Eds.), 1984. Seismicity and sedimentation (special issue). Mar. Geol. 55 (1/2), 493.

Cojan, I., Thiry, M., 1992. Seismically induced deformation structures in Oligocene shallow-marine and eolian coastal sands (Paris Basin). Tectonophysics 206, 79-89.

Cole, R.D., Picard, M.D., 1975. Primary and secondary structures in oil shale and other fine grained rocks, Green River Formation (Eocene), Utah and Colorado, Utah. Geology 2, 49-67.

Davenport, C.A., Ringrose, P.S., 1987. Deformation of Scottish Quaternary sediment sequences by strong earthquake motions. In: Jones, M.E., Preston, R.M.F. (Eds.). Deformation of Sediments and Sedimentary Rocks, Geol. Soc. Spec. Publ. 29 Blackwell, Oxford, pp. 299-314.

Einsele, G., Ricken, W., Seilacher, A. (Eds.), 1991. Cycles and Events in Stratigraphy Springer, Berlin (955pp.).

Einsele, G., Chough, S.K., Shiki, T. (Eds.), 1996. Depositional events and their records-an introduction, Sediment. Geol. 104 (255pp.).

Elizaga, E., 1994. Análisis de facies sedimentarias y petrología de los depósitos lacustres de edad Neógeno superior de la Zona Prebética, Albacete, España. Inst. Estudios Albacetenses, Albacete, 216pp.

Elizaga, E., Calvo, J.P., 1988. Evolución sedimetaria de las cuencas lacustres neógenas de la zona prebética (Albacete, España). Relación, posición y efectos del vulcanismo durante la evolución. Bol. Geol. Minero 96, 837-846.

Gibling, M.R., Tantisukrit, C., Uttamo, W., Thanasuthipitak, T., Haraluk, M., 1985. Oil shale sedimentology and geochemistry in Cenozoic Mae Sot Basin, Thailand. Am. Assoc. Petr. Geol. Bull. 69, 767-780.

Glenn, C.R., Kelts, K., 1991. Sedimentary rhythms in lake deposits. In: Einsele, G., Ricken, W., Seilacher, A. (Eds.). Cycles and Events in Stratigraphy, Springer, Berlin, pp. 188-219. 
Grimm, K.A., Orange, D.L., 1997. Synsedimentary fracturing, fluid migration, and subaqueous mass wasting: intrastratal microfractured zones in laminated diatomaceous sediments, Miocene Monterey Formation, California, USA. J. Sediment. Res. 67, 601-613.

Guiraud, M., Plaziat, J.C., 1993. Seismites in the fluviatile Bima sandstones: identification of paleoseisms and discussion of their magnitudes in a Cretaceous synsedimentary strike-slip basin (Upper Benue, Nigeria). Tectonophysics 225, 493-522.

Hempton, M.R., Dewey, J.S., 1983. Earthquake-induced deformational structures in young lacustrine sediments, East Anatolian Fault, southeast Turkey. Tectonophysics 98, T14-T17.

Jiménez Sánchez, S., 1997. Formación de depósitos diatomíticos en cuencas neógenas del sureste de la provincia de Albacete. Instituto de Estudios Albacetenses, Albacete, 154pp.

Kuenen, P.H., 1958. Experiments in Geology. Trans. Geol. Soc. of Glasgow 23, 1-37.

Marco, S., Agnon, A., 1995. Prehistoric earthquake deformations near Masada, Dead Sea graben. Geology 23, 695-698.

Martel, A.T., Gibling, M.R., 1993. Clastic dykes of the DevonoCarboniferous Horton Bluff Formation, Nova Scotia: stormrelated structures in shallow lakes. Sediment. Geol. 87, 103119.

Martín Velázquez, S., Rodríguez Pascua, M.A., De Vicente, G., Calvo, J.P., 1998. Análisis dinámico del sistema de desgarres NO-SE del Prebático de Albacete. Rev. Soc. Geol. España 11 (3-4), 369-383.

McCalpin, J.P., 1996. Paleoseismology, Academic Press, San Diego (588pp.)

Montenat, C., Ott D’Estevou, P., Masse, P., 1987. Tectonic-sedimentary characters of the Betic Neogene basins evolving in a crustal transcurrent shear zone (SE Spain). Bull. Centres Rech. Explor.-Prod. Elf-Aquitaine 11, 1-22.

Obermaier, S.F., Martin, J.R., Frankel, A.D., Youd, T.L., Munson, P.J., Munson, C.A., Pond, E.C., 1993. Liquefaction evidence for one or more strong Holocene earthquakes in the Wabash Valley of southern Indiana and Illinois, with a preliminary estimate of magnitude. US Geol. Surv. Prof. Paper 1536, 27pp.

Owen, G., 1996. Experimental soft-sediment deformation: structures formed by the liquefaction of unconsolidated sands and some ancient examples. Sedimentology 43, 279-293.

Pettijohn, F.J., Potter, P.E., 1964. Atlas and Glossary of Primary Sedimentary Structures, Springer, Berlin (370pp.).

Plaziat, J.C., Ahamamou, M., 1998. Les différents mécanismes à l'origine de la diversité des séismites, leur identification dans le
Pliocène du Saïs de Fès et de Meknès (Maroc) et leur signification tectonique. Geodinamica Acta 11, 183-203.

Pratt, B.R., 1998. Molar-tooth structure formation by earthquakeinduced shrinkage and how it aids tectonic, paleoceanographic and paleobathymetric reconstruction of Precambrian basins. Abstracts, 15th International Sedimentological Congress, Alicante, Spain, p. 635.

Ricci Lucchi, F., 1995. Sedimentological indicators of paleoseismicity. In: Serva, L., Slemmons, D.B. (Eds.). Perspectives in Paleoseismology, Association of Engineering Geologists Special Publication No. 6, pp. 7-17.

Rodríguez-Pascua, M.A., 1998. Paleosismicidad y sismotectónica de las cuencas lacustres neógenas del Prebético de Albacete. $\mathrm{PhD}$ thesis, Universidad Complutense, Madrid, 358pp.

Rodríguez-Pascua, M.A., De Vicente, G., Ramírez Rayo, M.S., Martín Velázquez, S., Calvo, J.P., 1996. Periodos de recurrencia de paleoterremotos en sedimentos varvados lacustres del Mioceno superior Cuenca de Híjar (Albacete). Geogaceta 20 (4), 1004-1007.

Sanz de Galdeano, C., Vera, J.A., 1992. Stratigraphic record and palaeogeographical context of the Neogene basins in the Betic Cordillera, Spain. Basin Res. 4, 21-36.

Scott, B., Price, S., 1988. Earthquake-induced structures in young sediments. Tectonophysics 147, 165-170.

Seilacher, A., 1969. Fault graded beds interpreted as seismites. Sedimentology 13, 155-159.

Serva, L., Slemmons, D.B (Eds.), 1995. Perspectives in Paleoseismology Association of Engineering Geologists, Special Publication No. 6 (139pp.).

Sims, J.D., 1973. Earthquake-induced structures in sediments of Van Norman Lake, San Fernando, California. Science 182, 161-163.

Sims, J.D., 1975. Determining earthquake recurrence intervals from deformational structures in young lacustrine sediments. Tectonophysics 29, 141-152.

Stewart, A.D., 1963. On certain slump structures in the Tortonian sandstones of Apple-Cross. Geol. Mag. 100, 205-218.

Trewin, N.H., 1986. Palaeoecology and sedimentology of the Achanarras fish bed of the Middle Old Red Sandstone, Scotland. Trans. R. Soc. Edinburgh, Earth Sci. 77, 21-46.

Van der Beek, P.A., Cloething, S., 1992. Lithospheric flexure and the tectonic evolution of the Betic Cordilleras (SE Spain). Tectonophysics 203, 325-344.

Yeats, R.S., Sieh, K., Allen, C.R., 1997. The Geology of Earthquakes, Oxford University Press, New York (568pp.). 